\title{
Evaluation of physicochemical, functional and microbiological properties of naturally fermented EVIARC sweet jackfruit (Artocarpus heterophyllus Lam.) seed flour
}

\author{
Maria Norfrelij J. Cuadra ${ }^{*}$, Lorina A. Galvez ${ }^{2}$ and Felix J. Amestoso ${ }^{2}$
}

\begin{abstract}
Jackfruit seeds are rich in carbohydrates and protein. It can be processed into flour as a nutritious product which can be stored for future use. However, jackfruit seed flour has limited cooking applications, thus, the need to improve its functionality through natural fermentation process. The study was conducted to determine the effects of lactic acid and fermentation time on the physicochemical, functional and microbiological properties of the fermented jackfruit seed flour, compared to its unfermented counterpart.

A $3 \times 3$ full factorial design following Completely Randomized Design (CRD) with different levels of lactic acid $(0,1.5,3 \%)$ and fermentation time $(16,24,32$ hours) and with a control treatment was used. Data for all experimental combinations were analyzed using One-way ANOVA where means were compared using Tukey's HSD.

Analysis of variance results revealed that the physico-chemical and functional properties of control treatment is significantly different from the fermented jackfruit flour in terms of $\mathrm{pH}$, moisture and carbohydrates. Moreover, fermentation and lactic acid contributed to increase in quality values of the jackfruit flour except for \%energy, \%carbohydrates and bulk density. The faster drop in $\mathrm{pH}$ brought about by lactic acid increased the count of aerobic bacterial, lactic acid bacteria, yeasts and molds.
\end{abstract}

Keywords: fermentation, jackfruit seeds flour, physico-chemical, functional properties, microbial monitoring

\section{INTRODUCTION}

At present, functional foods have spiked the interest of many health conscious individual and the food industry. According to the report of the Institute

${ }^{1}$ Department of Arts and Sciences, Visayas State University- Tolosa, Tolosa, Leyte, Philippines

${ }^{2}$ Department of Food Science and Technology, Visayas State University, Visca, Baybay City, Leyte, Philippines

* Corresponding Author. Address: Department of Arts and Sciences, Visayas State University- Tolosa, Tolosa, Leyte, Philippines Tel: +639368121402 E-mail: mncuadra1995@gmail.com DOI: 10.32945/atr4018.2018 
Evaluation of physicochemical, functional and microbiological properties

of Food Technologists (2009), functional food is defined as "foods and food components that provide a health benefit beyond basic nutrition, either adding new ingredients or more of that existing ingredient, to provide health benefits or desirable physiological effects". The jackfruit fits in to the definition because of the valuable compounds in different parts of the fruit that displays functional effects, including the seeds. However, its seeds have shorter shelf life and germinate immediately after maturity. Fresh seeds are quite difficult to store and with lack of processing and preservation techniques, seeds are usually wasted during seasonal glut (Butool \& Butool 2013, Hossain et al 2014).

To avert wastage of jackfruit seeds, they can be transformed into flour, an alternative product which can be stored and utilized for a longer duration. Jackfruit seed flour has been used particularly as an alternative ingredient that can be blended with other flours for value addition in bakery and bread preparation (Hossain et al 2014). But, compared to wheat flour, jackfruit seeds flour has limited cooking properties, particularly in baking, thus there's a need to improve its functionality to further expand its range of application. An improved version of jackfruit seeds flour can be attained through fermentation where the growth of microbes will produce enzymes to give the desired product, as what is being done in cassava starch (Julianti et al 2011, Vatanasuchart et al 2003). Therefore, this study is undertaken to assess the qualitative properties of the developed naturally fermented jackfruit seed flour compared to the unfermented jackfruit seed flour.

\section{MATERIALS AND METHODS}

\section{Fermented Jackfruit Seeds Flour Preparation}

Seed Collection and Treatment. EVIARC Sweet Jackfruit (Artocarpus heterophyllus Lam.) seeds were collected from the Department of Food Science and Technology during processing of vacuum fried and dehydrated jackfruit products. The collected seeds were washed with tap water to remove impurities. The white aril (seed coats) was peeled off manually. Then it was soaked in $3 \%$ sodium hydroxide for $3-5 \mathrm{~min}$ at room temperature to remove the brown layers (spermoderm covering) and washed with running tap water again. The cotyledon was used to prepare the flour.

Fermented Jackfruit Seed Flour Preparation and Processing. The freshly washed seeds were sliced into small pieces, dried in a cabinet dryer for 6 hours and pre-ground with a grinder. The pre-ground seeds were fermented by submerging in distilled water at a ratio of 1:2 w/v as described by Igbabul et al (2014) with modifications. Pre-ground seeds were incubated in 1-3\% lactic acid solution at room temperature for 16-32h.

After fermentation the liquid was decanted and the sample was dried to reduce the moisture. Dried flour samples were pulverized and sieved in a 70 mesh size. The obtained flour was packed in polyethylene bags and stored at room temperature until further analysis. Unfermented jackfruit seed flour (control treatment) was also prepared. 


\section{Experimental Design}

A $3 \times 3$ full factorial design using three levels of variables following the Completely Randomized Design (CRD) was employed in the study generating nine treatments for experimental combinations and together with a control treatment (Table 1). This experimental design was used for the product formulation using three levels of lactic acid concentration $(0,1.5$ and $3 \% \mathrm{v} / \mathrm{v})$ and fermentation time $(16,24$ and $32 h)$.

Table 1. A $3 \times 3$ full factorial design of experiment with 2 variables for experimental combinations for fermented jackfruit seeds flour and a control treatment

\begin{tabular}{ccc}
\hline Treatment & Lactic Acid (\% v/v) & Fermentation Time (h) \\
\hline 0 (control) & 0 & 0 \\
1 & 0 & 16 \\
2 & 0 & 24 \\
3 & 0 & 32 \\
4 & 1.5 & 16 \\
5 & 1.5 & 24 \\
6 & 1.5 & 32 \\
7 & 3 & 16 \\
8 & 3 & 24 \\
9 & 3 & 32 \\
\hline
\end{tabular}

\section{Determination of Physico-chemical Properties}

$\mathrm{pH}$ evaluation. The $\mathrm{pH}$ was measured using a $\mathrm{pH}$ meter (Boeco Germany Model PT-70). Five grams of the sample thoroughly mixed with $25 \mathrm{~mL}$ distilled water was used for sample measurement. Measurement was done in three trials.

Titratable Acidity (TA) Determination. The TA (lactic acid as predominant acid) was determined by employing the standard titration method using a standardized $\mathrm{NaOH}$ solution. Five grams of the sample was suspended in $90 \mathrm{~mL}$ of distilled water in a volumetric flask. Then it was added with 2-3 drops of phenolphthalein indicator. It was then titrated with standardized $0.1 \mathrm{~N} \mathrm{NaOH}$ solution until a stable pinkish color was observed. Measurement was done in three replicates.

Aw Measurement. Smart Water Activity Meter (Model HD-3A) was used to evaluate the water activity. This method was replicated three times with $5 \mathrm{~g}$ of samples each.

Proximate and Nutritional Analysis. The moisture (by oven drying), ash (by gravimetric method), crude fiber (modified frtitted glass crucible), protein (kjeldahl method), fat (soxhlet extraction), carbohydrates (by computation) and energy (by computation) of the 10 treatments (including the control) were analyzed by submitting the samples to the Intertek Testing Services Philippines, Inc. 
Evaluation of physicochemical, functional and microbiological properties

\section{Determination of Functional Properties}

The swelling power, water and oil absorption and bulk density were performed in three replications.

Swelling Power. Swelling power was determined using the method employed by Leach et al (1959). About $0.1 \mathrm{~g}$ sample was added with $10 \mathrm{~mL}$ distilled water then heated in a water bath at $60^{\circ} \mathrm{C}$ for $30 \mathrm{~min}$ with constant stirring. The sample was centrifuged at $1600 \mathrm{rpm}$ for $15 \mathrm{~min}$. The precipitate was weighed and calculated as $\mathrm{g} / \mathrm{g}$ weight of sedimental paste/weight of the sample.

Water and Oil Absorption Analysis. This was determined using the method employed by Julianti et al (2011) with little modification. About $1 \mathrm{~g}$ of sample was suspended in $10 \mathrm{~mL}$ distilled water (for water absorption) or vegetable oil (for oil absorption) vortexed thoroughly and centrifuged at $2500 \mathrm{rpm}$ for $10 \mathrm{~min}$ (for water absorption) or $30 \mathrm{~min}$ (for oil absorption). The supernatant was poured carefully into a tared evaporating dish. Water- or oil absorption capacity was calculated as $(\mathrm{g} / \mathrm{g}): 1$ weight of wet sediment/initial weight of flour.

Bulk Density. This was determined using the method of Narayana and Narasinga Rao (1984). A graduated cylinder was weighed and the flour sample was added up to $5 \mathrm{~mL}$ mark by constant tapping. The contents were weighed and the difference in weight determined. The bulk density was computed as grams per milliliter of the sample.

\section{Microbial Analysis and Monitoring}

Monitoring of the growth of total microorganisms (bacteria, molds, yeast and lactic acid bacteria) in fermented jackfruit seed flour samples was calculated by Total Viable Count (TVC) method and expressed by log colony forming unit (log $\mathrm{cfu} / \mathrm{mL}$ ). Microbial analysis was done at the Microbiology Laboratory of the Department of Food Science and Technology, Visayas State University. A rapid selective enzyme- based $3 \mathrm{M}^{\mathrm{TM}}$ petrifilm count plates were used for aerobic count plate, yeast and molds. Monitoring for lactic acid bacteria was done by plating with MRS agar. Dilution of sample up to $10^{-5}$ was employed and dilution factors $10^{-2}, 10^{-3}$, $10^{-4}$ and $10^{-5}$ were used for plating ( 2 replicates). Monitoring was done every 4 hours for the entire duration of the fermentation experiment.

\section{Statistical Analysis}

The data gathered were subjected to One-way Analysis of Variance (ANOVA) using STATISTICA version 8. For the significant results, treatment means were compared using Tukey's HSD. Average response means were analyzed using Microsoft Excel 2013.

\section{RESULTS AND DISCUSSION}

\section{Physico-chemical and Functional Properties of Fermented Jackfruit Seed Flour}

The result of analysis of variance revealed that the physico-chemical and functional properties of control treatment is significantly different from the 
fermented jackfruit seeds flour in terms of $\mathrm{pH}$, moisture and carbohydrates. Moreover, fermentation and lactic acid contributed to the increase of quality values of the jackfruit seed flour (JSF) except for \%energy, \%carbohydrates and bulk density.

The percent titratable acidity (\%TA) values of the different treatments ranged from $0.04 \%$ to $0.44 \%$. Subjecting the flours to fermentation and incorporation of lactic acid in the process provide an increase in \%TA of the JSF (Table 2). It is also revealed that increase in \%TA correspond to drop in $\mathrm{pH}$ (values ranged from 3.90 to $5.71)$ throughout fermentation process. This can be attributed to the formation of natural acids, the lactic acid, caused by the activity of fermenting microorganisms.

Significant increase in Aw (values ranged from 0.65 to 0.99 ) and moisture (values ranged from 7.55 to 21.56) content of the fermented JSF was observed. This could be contributed by increased lactic acid and longer duration of fermentation process caused the product to become hygroscopic in nature. The granular structure of the JSF could have been modified as supported by the acidity alterations caused by enzymatic reactions from microbial activity (Adejumo 2013). Water molecules are strongly bound to hydrophilic biopolymers, such as proteins and polysaccharides, present in the flour or starch during fermentation (Chiste et al 2015).

The ash and protein content of the control treatment is not by much significantly different compared to the fermented treatments. However, a relative increase in ash (values ranged from 2.47 to 3.31 ) and protein (values ranged from 8.48 to 9.03 ) content can be attained when JSF is fermented. This can possibly be due to the increase in microbial mass during fermentation causing hydrolysis of the protein molecules to amino acids and other simple peptides (Igbabul et al 2014).

Unfermented JSF is found to be not significantly different from the fermented JSF except T9 where it comprises the highest level of incorporated lactic acid and longest fermentation time. The result suggests that probably further increase in both variables might result to a more significant increase in fat values. The fat values ranged from 0.8 to 1.24 .

Fermentation process significantly decreases the carbohydrate content of the flours as possibly caused by fermenting microbes, most probably the homofermentative lactic acid bacteria, theoretically produces lactic acid using a carbon source (sugar) from carbohydrates. These sugars enter major pathways in glycolysis and further steps in fermentation process converting it into pyruvic acid. Pyruvic acid is then reduced to lactic acid as the final reaction of fermentation process (Halasz 2011). Furthermore, energy values showed no significant differences between treatments. A relative decrease in energy content can be observed which can be attributed to the decrease in carbohydrate content as it is the main source of energy (among three forms of energy/calories -fat, protein and carbohydrates). The energy content values of the different treatments ranged from 305.00 to 365.56 whereas for carbohydrate contents ranged from 65.49 to 78.62 .

The presence of suitable enzymes produced by fermenting microbes caused utilization and break down of fiber components of JSF thus, the increased values ranging from 1.34 to 2.64 .

On Table 3, the unfermented JSF's swelling power, water absorption capacity (WAC) and oil absorption capacity (OAC) were not significantly different from its fermented counterparts. 
Evaluation of physicochemical, functional and microbiological properties

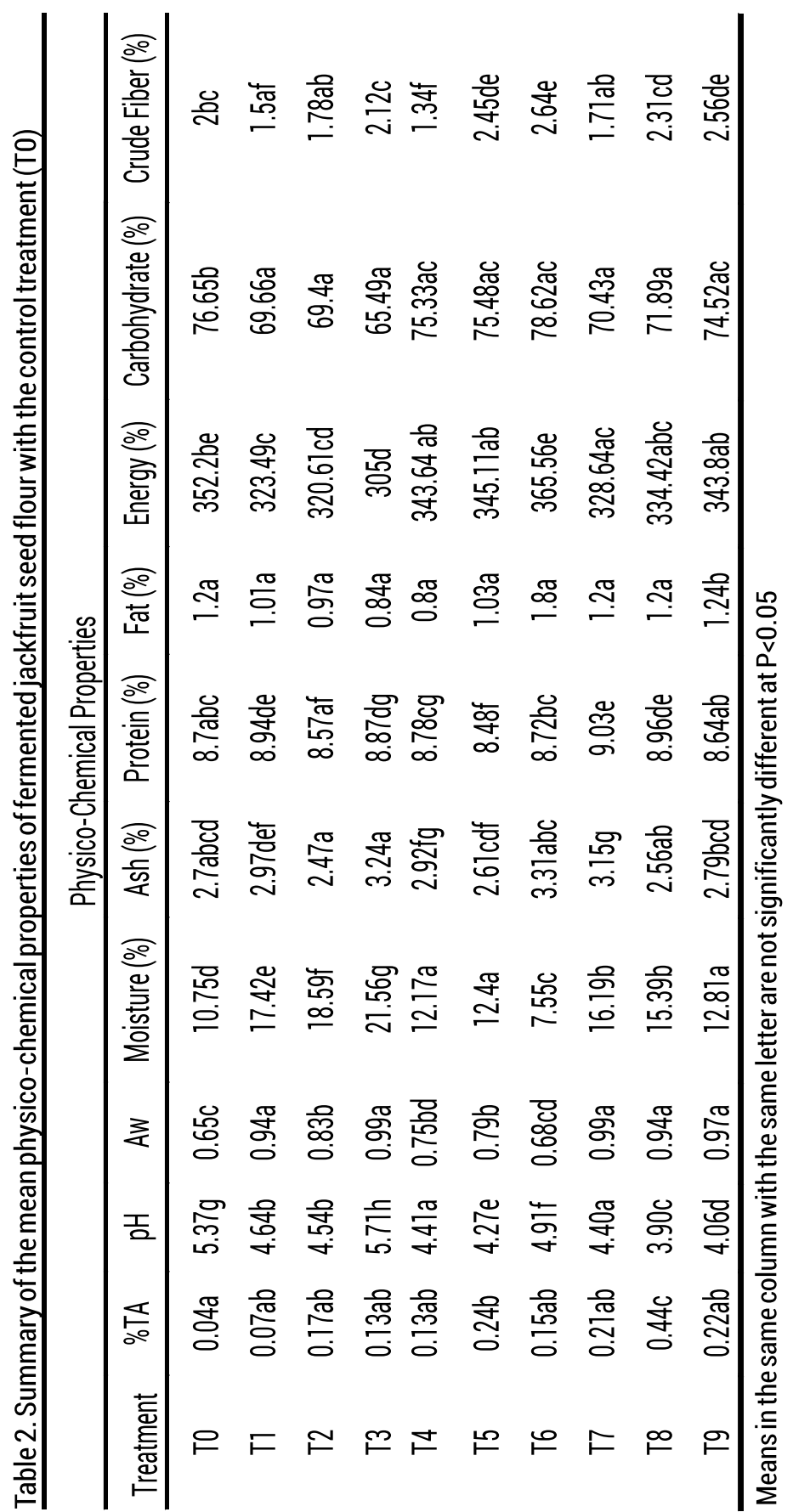


Table 3. Summary of the mean physico-chemical properties of fermented jackfruit seed flour with the control treatment (T0)

\begin{tabular}{ccccc}
\hline \multicolumn{5}{c}{ Functional Properties } \\
\hline Treatment & $\begin{array}{c}\text { Swelling } \\
\text { Power }\end{array}$ & $\begin{array}{c}\text { WAC } \\
\left(\mathrm{g} \cdot \mathrm{g}^{-1}\right)\end{array}$ & $\begin{array}{c}\text { OAC } \\
\left(\mathrm{g} . \mathrm{g}^{-1}\right)\end{array}$ & Bulk Density $(\mathrm{g} / \mathrm{ml})$ \\
\hline T0 & $6.30 \mathrm{a}$ & $2.39 \mathrm{ab}$ & $0.96 \mathrm{abc}$ & $0.93 \mathrm{c}$ \\
T1 & $8.15 \mathrm{a}$ & $3.01 \mathrm{~cd}$ & $1.08 \mathrm{~cd}$ & $0.67 \mathrm{ab}$ \\
T2 & $6.08 \mathrm{a}$ & $2.66 \mathrm{abc}$ & $1.11 \mathrm{~d}$ & $0.63 \mathrm{ab}$ \\
T3 & $8.40 \mathrm{a}$ & $2.79 \mathrm{bcd}$ & $0.95 \mathrm{ab}$ & $0.67 \mathrm{ab}$ \\
T4 & $7.23 \mathrm{a}$ & $2.28 \mathrm{a}$ & $1.06 \mathrm{abcd}$ & $0.67 \mathrm{ab}$ \\
T5 & $5.26 \mathrm{a}$ & $2.37 \mathrm{ab}$ & $0.95 \mathrm{a}$ & $0.67 \mathrm{ab}$ \\
T6 & $7.64 \mathrm{a}$ & $2.63 \mathrm{abc}$ & $0.97 \mathrm{abc}$ & $0.77 \mathrm{bc}$ \\
T7 & $8.61 \mathrm{a}$ & $3.13 \mathrm{abcd}$ & $1.00 \mathrm{abcd}$ & $0.47 \mathrm{a}$ \\
T8 & $5.59 \mathrm{a}$ & $2.53 \mathrm{abcd}$ & $1.03 \mathrm{abcd}$ & $0.50 \mathrm{a}$ \\
T9 & $7.17 \mathrm{a}$ & $2.25 \mathrm{bcd}$ & $1.07 \mathrm{bcd}$ & $0.53 \mathrm{ab}$ \\
\hline
\end{tabular}

Means in the same column with the same letter are not significantly different at $P<0.05$

On the other hand, the bulk densities of the fermented flours in this study were lower than the unfermented counterpart. Lower bulk density has advantage as it is easier to transport as it is lighter and offers greater advantage to preparation of complementary foods such as infant and child food formulations (David et al 2015, Owen 2001). Values of bulk densities of the different treatment ranged from 0.47 to $0.93 \mathrm{~g} / \mathrm{ml}$.

\section{Microbial and pH Monitoring of Fermentation Set-ups}

At $0 \%$ lactic acid, there was a rapid decrease of $\mathrm{pH}$. On the other hand, set-ups with 1.5 and $3 \%$ lactic acid showed a slight gradual dropping of $\mathrm{pH}$ at which the values were almost the same (Figure 1). Decrease in $\mathrm{pH}$ values throughout fermentation implies growth of acid forming microorganisms.

The summary of growth of the different microorganisms computed in log $\mathrm{cfu} / \mathrm{mL}$ are shown in Table 4 while Figures $2 \mathrm{a}-2 \mathrm{~d}$ shows the growth of aerobic bacteria, lactic acid bacteria (LAB), yeasts and molds monitored.

Figure 2a shows that significant increase in aerobic microbial growths is observed starting towards $4 \mathrm{~h}$ of fermentation for both $0 \%$ and $1.5 \% \mathrm{LA}$ and around $12 \mathrm{~h}$ of fermentation for $3 \% \mathrm{LA}$. It is also observed for $0 \% \mathrm{LA}$ that the microbial growth gradually starts to drop at the 12th to 28th hours of fermentation however, but made a significant comeback at the end of the fermentation period (32nd hour). The microbial population of aerobic microorganisms for $0 \%$ LA ranged from 5.70 to 
Evaluation of physicochemical, functional and microbiological properties

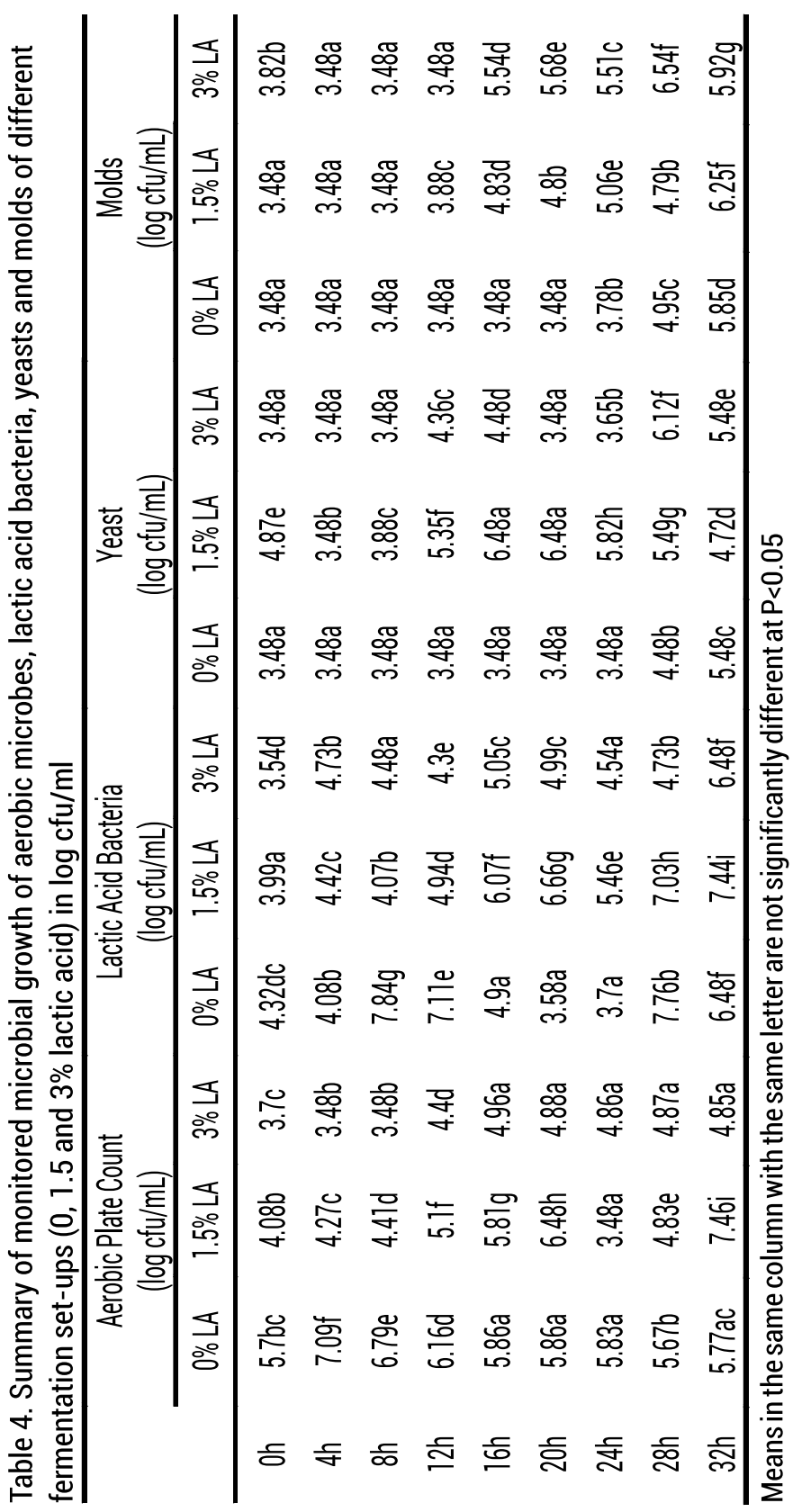


$5.77 \mathrm{log}$ cfu/mL. At $1.5 \% \mathrm{LA}$, the microbial growth significantly increased from 4.08 to $7.46 \mathrm{log} \mathrm{cfu} / \mathrm{mL}$ after $32 \mathrm{~h}$ of fermentation. Although at some point at 24 th hour, the growth suddenly dropped. This can be attributed to the environment becoming acidic which makes the microbes momentarily unable to withstand and could have taken some time to adapt. An almost constant growth of microorganisms can be observed at the 16th hour up to the very end of fermentation for the $3 \% \mathrm{LA}$.

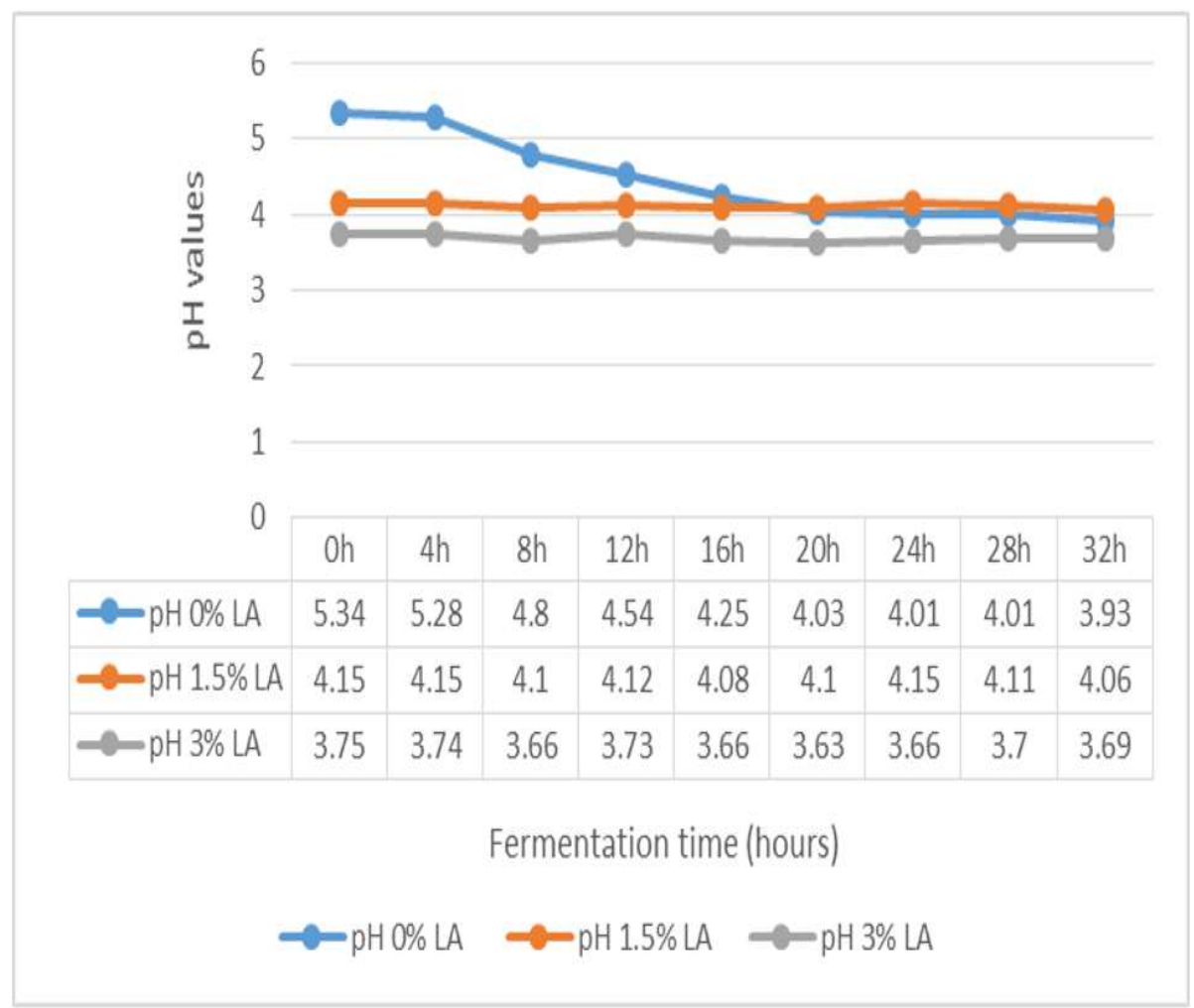

Figure 1. $\mathrm{pH}$ changes monitored for every 4 hours throughout the $32 \mathrm{~h}$ fermentation process with different lactic acid concentrations 
Evaluation of physicochemical, functional and microbiological properties

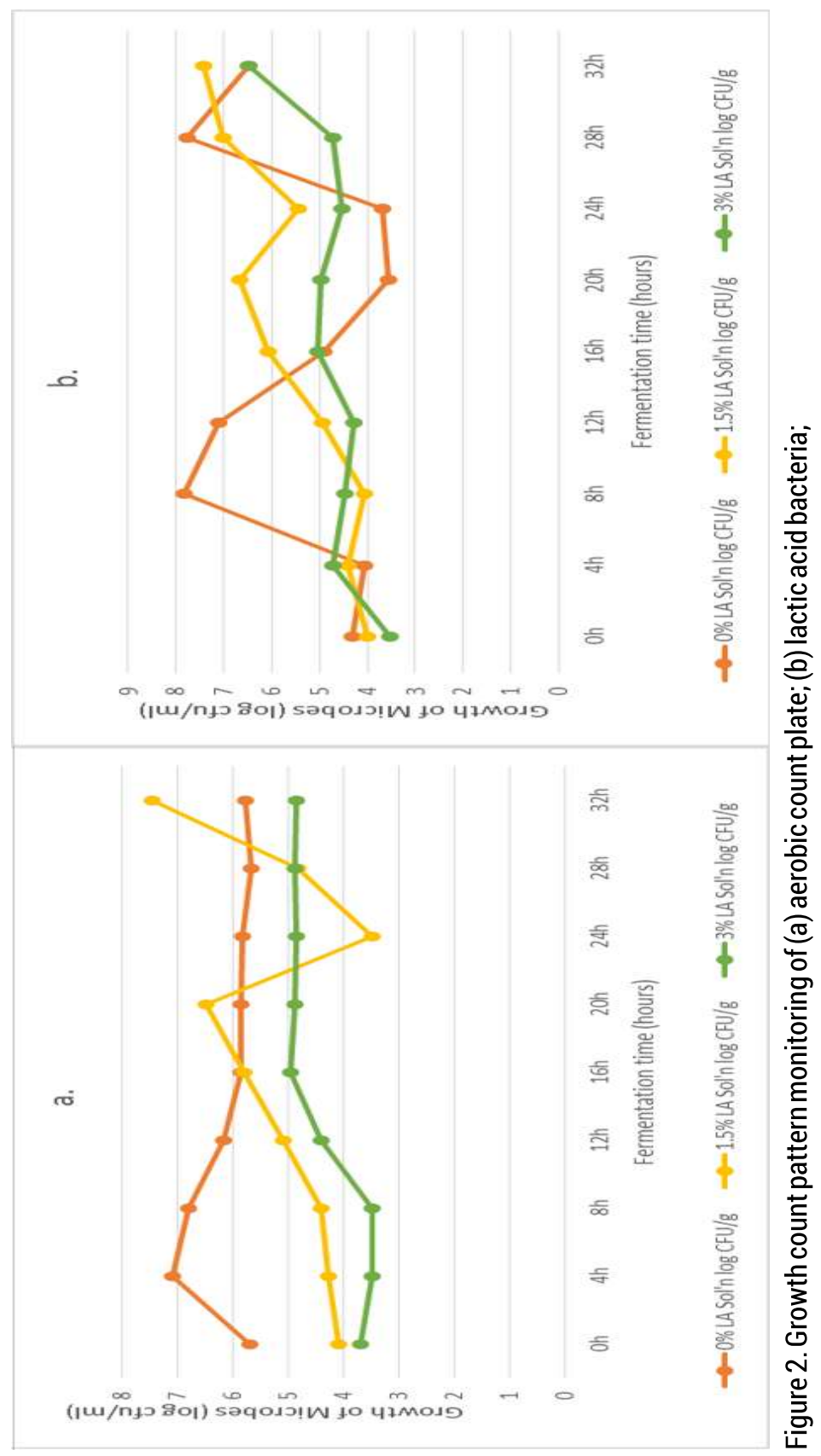


Cuadra, Galvez \& Amestoso

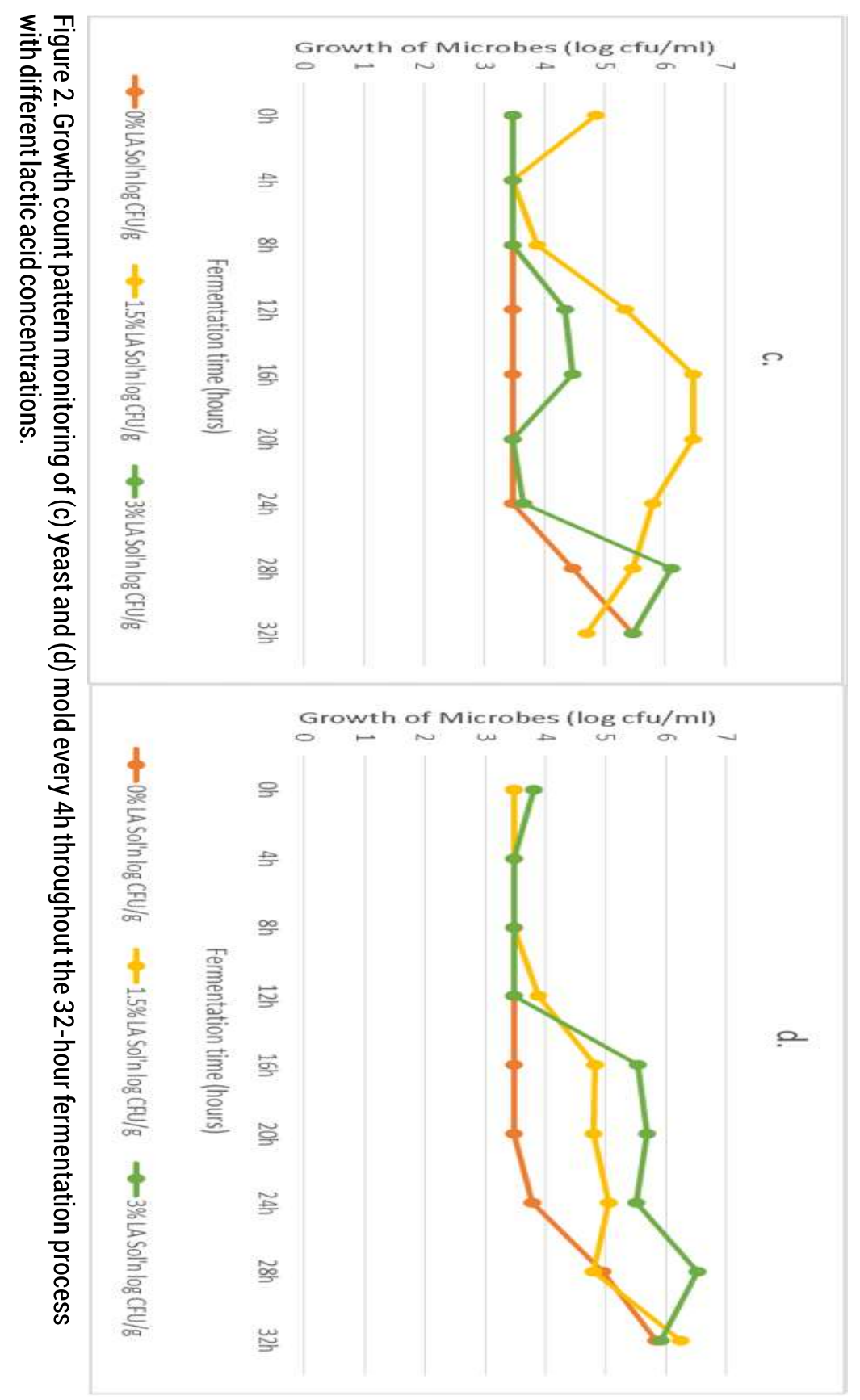


Evaluation of physicochemical, functional and microbiological properties

The growth of microorganisms in $3 \%$ LA reached to $4.85 \log \mathrm{cfu} / \mathrm{mL}$ from 3.7 $\log \mathrm{cfu} / \mathrm{mL}$. The results revealed that presence of lactic acid in the solution during fermentation can instigate more aerobic bacterial growth at a given fermentation time. This growth generally refers to total number of microorganisms that grow under aerobic conditions in moderate temperature. This study assumes such growth refers to microorganisms associated with fermented products such as lactic acid producing bacteria and yeasts. However, such assumptions can be supported by the results of lactic acid bacteria ( $L A B)$ and yeasts growth monitoring from this study.

Figure $2 \mathrm{~b}$ shows the growth trend for LAB. Growth of LAB at $0 \%$ LA showed an inconsistent pattern. The growth is at its peak at $8 \mathrm{~h}$ of fermentation but showed significant decrease until the 24th hour. But then, growth jolted at the 28th hour of fermentation then significantly decreased again at the last hour of fermentation. However, the population of LAB at $0 \%$ LA showed significant increase from 4.32 to $6.48 \mathrm{log} \mathrm{cfu} / \mathrm{mL}$. For both 1.5 and $3 \% \mathrm{LA}$, the growth of the LAB showed a gradual increase from the start to the final stage of fermentation. The gradual growth of $\mathrm{LAB}$ can be supported also with the gradual decrease in $\mathrm{pH}$ during the fermentation process (Figure 1). The LAB growth significantly increased from 3.99 to $7.44 \mathrm{log}$ $\mathrm{cfu} / \mathrm{mL}$ for $1.5 \% \mathrm{LA}$ and 3.54 to $6.48 \mathrm{log} \mathrm{cfu} / \mathrm{mL}$ for $3 \% \mathrm{LA}$

The results revealed that presence of lactic acid in a solution provides faster drop in $\mathrm{pH}$ at a given fermentation time which is conducive to higher LAB population.

In the case of growth of yeast (Figure 2c), it shows increase in population similar to the LAB growth particularly at $3 \%$ lactic acid (Figure $3 \mathrm{~b}$ ) although there was a significant decrease in yeast growth at the $32 \mathrm{nd}$ hour. This maybe attributed to their symbiotic association where $L A B$ create an acidic environment conducive to yeast proliferation while yeast provide vitamins and growth factors for LAB (Gobbetti et al 1994, Steinkraus 1996). The yeast growth at 3\% LA began with 3.48 $\log \mathrm{cfu} / \mathrm{mL}$ population to $5.48 \mathrm{log} \mathrm{cfu} / \mathrm{mL}$ at $32 \mathrm{~h}$ of fermentation. In contrast to the growth pattern of the $L A B$ in $0 \%$ LA which is quite erratic but still showed increase in growth at the end, the yeast growth in $0 \%$ LA showed almost a constant growth until the 24th hour of fermentation and significantly increased until the end of fermentation. Yeast growth reached $5.48 \mathrm{log} \mathrm{cfu} / \mathrm{mL}$ from $3.48 \mathrm{log} \mathrm{cfu} / \mathrm{mL}$ after $32 \mathrm{~h}$ fermentation. On the other hand, yeast growth for $1.5 \%$ lactic acid decreases significantly from the 20th hour until the end of fermentation. This could be due to competition and depletion of nutrients by yeast, formation of ethanol and other inhibitory compounds produced by microbial metabolism (Dharmadhikarind). The yeast population at $1.5 \%$ was $4.87 \mathrm{log} \mathrm{cfu} / \mathrm{mL}$ and decreased to $4.72 \mathrm{lof} \mathrm{cfu} / \mathrm{mL}$ at the end of fermentation process. The acidity of the environment which the $1.5 \%$ lactic acid provided may not be acidic enough for yeast growth.

Molds growth was observed to proliferate faster in fermentation set-up with lactic acid in the solution. At 1.5 and $3 \%$ lactic acid, increase in molds' growth was observed as early as the 16th hour of fermentation compared to set-up with no lactic acid which molds were observed thriving at the later stage (24th hour) of fermentation (Figure 2d). Such phenomenon can be attributed to the molds' tolerance at low $\mathrm{pH}$ environment which fermentation set-ups of 1.5 and $3 \%$ lactic acid can offer even at lesser fermentation time. The molds reached from 3.48 to $5.85 \mathrm{log} \mathrm{cfu} / \mathrm{mL}, 3.48$ to $6.25 \mathrm{log} \mathrm{cfu} / \mathrm{mL}$ and 3.82 to $5.92 \mathrm{log} \mathrm{cfu} / \mathrm{mL}$ for $0,1.5$ and $3 \%$ LA, respectively. 


\section{CONCLUSION}

The results have provided improved properties of the jackfruit seed flour in majority of its quality properties except for \% energy, \% carbohydrates and bulk density when fermented with lactic acid solution. This indicates fermented JSF outstanding potential in the food systems.

\section{RECOMMENDATIONS}

Microbial identification should be done to further investigate the strains of microorganisms that grew during fermentation. An actual shelf-life evaluation should also be performed to determine specific period of time the product will be considered safe for use. The fermented treatments should be tested for cooking application, specifically in baking.

\section{ACKNOWLEDGMENT}

The authors would like to thank the Department of Science and Technology -Science Education Institution (DOST-SEI) Accelerated Science and Technology Human Resource Development Program-National Science Consortium (ASTHRDP-NSC) for the funding support in the conduct of the study.

\section{REFERENCES}

Hossain MT, Hossain MM, Sarker M, Shuvo AN, Alam MM \& Rahman MS. 2014. Development and Quality Evaluation of Bread Supplemented with Jackfruit Seed Flour. International J Nutrition \& Food Sciences, 3(5):484-487. doi: 10.11648/j.ijnfs.20140305.28

Butool S and Butool M. 2013. Nutritional Quality on Value Addition to Jackfruit Seed Flour. International J Science \& Research, 4(4): 2319-7064.

Vatanasuchart N, Naivikul O, Charoenrein S \& Sriroth K. 2003. Effects of different UV irradiations on properties of cassava starch and biscuit expansion. Kasetsart J National Science, 37:334-340

Julianti E, Lubis Z, Radiwansyah E, Yusraini E \& Suhaidi I. 2011. Physicochemical and Functional Properties of Fermented Starch from Four Cassava Varieties. Asian J Agricultural Research, 5:292-299.

Adejumo BA. 2013. Some quality attributes of locally produced wheat flour storage. J Environmental Science, Toxicology \& Food Technology, 5(2):47-49.

Chiste RC, Cardoso JM, De Silva DA \& De Silva PENA R. 2015. Hygroscopic behaviour of cassava flour from dry and water groups. Cienca Rural, 45(8):1515-1521. Accessed at http://dx.doi.org/10.1590/0103$8478 \mathrm{cr} 2014338$

Igbabul B, Hiikyaa O \& Amove J. 2014. Effect of fermentation on the proximate composition and functional properties of mahogany bean (Afzelia africana) flour. Nutrition \& Food Science, 2(1):1-7.

Halasz A. 2011. Lactic Acid Bacteria. Food Quality \& Standards, 3:1-6.

Owen G. 2001. Cereal Processing Technology. Wood Head Publishing, Cambridge. 
Evaluation of physicochemical, functional and microbiological properties

David O, Arthur E, Kwadwo SO, Badu E \& Sakyi P. 2015. Proximate Composition and Some Functional Properties of Soft Wheat Flour. International J Innovative Research in Science, Engineering \& Technology, 4(2):753-758.

Gobbetti M, Corsetti A \& Rossi J. 1994. The sourdough microflora. Interactions between lactic acid bacteria and yeasts: metabolism of amino acids. World $\mathrm{J}$ Microbiology \& Biotechnology, 10(3):275-279. doi:10.1007/BF00414862

Steinkraus KH. 1996. Handbook of Indigenous Fermented Foods (2nd ed). Marcel Dekker Inc.

Dharmadhikari M. nd. Lactic Acid Bacteria and Wine Spoilage. lowa State University Extension and Outreach. Accessed at http://www.extension.iastate.edu/wine/ lactic-acid-bacteria-and-wine-spoilage

Leach HW, Cowen MC, Schoch LD \& Schoch TJ. 1959. Structure of the starch granules in swelling and solubility patterns of various starches. Cereal Chemistry, 36:534-544.

Institute Of Food Technologists. 2009. Functional Foods: Opportunities and Challenges. Accessed at http://www.ift.org

Narayana K and Narasinga Rao MS. 1984. Effect of partial proteolysis on the functional properties of winged pea (Psophocarpus tetragonolobus) flour. $J$ Food Science, 49:944-947. 